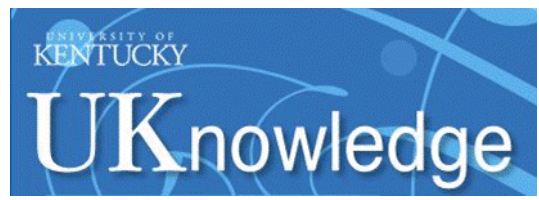

University of Kentucky

UKnowledge

\title{
Urbanization and Stream Salamanders: A Review, Conservation Options, and Research Needs
}

Kyle Barrett

Clemson University

Steven J. Price

University of Kentucky, steven.price@uky.edu

Follow this and additional works at: https://uknowledge.uky.edu/forestry_facpub

Part of the Forest Sciences Commons

Right click to open a feedback form in a new tab to let us know how this document benefits you.

\section{Repository Citation}

Barrett, Kyle and Price, Steven J., "Urbanization and Stream Salamanders: A Review, Conservation Options, and Research Needs" (2014). Forestry and Natural Resources Faculty Publications. 3.

https://uknowledge.uky.edu/forestry_facpub/3

This Article is brought to you for free and open access by the Forestry and Natural Resources at UKnowledge. It has been accepted for inclusion in Forestry and Natural Resources Faculty Publications by an authorized administrator of UKnowledge. For more information, please contact UKnowledge@lsv.uky.edu. 


\title{
Urbanization and Stream Salamanders: A Review, Conservation Options, and Research Needs
}

\author{
Digital Object Identifier (DOI) \\ http://dx.doi.org/10.1086/677556 \\ Notes/Citation Information
}

Published in Freshwater Science, v. 33, no. 3, p. 927-940.

(C) 2014 by The Society for Freshwater Science.

The copyright holders have granted the permission for posting the article here. 


\title{
Urbanization and stream salamanders: a review, conservation options, and research needs
}

\author{
Kyle Barrett ${ }^{1,3}$ and Steven J. Price ${ }^{2,4}$ \\ ${ }^{1}$ School of Agricultural, Forest, and Environmental Sciences, Clemson University, Clemson, South Carolina 29634-0317 USA \\ ${ }^{2}$ Department of Forestry, University of Kentucky, Lexington, Kentucky 40546-0073 USA
}

\begin{abstract}
Urban areas are increasing in size and human population density. The implications of widespread urbanization are apparent for a wide variety of stream organisms, but the responses of stream-dwelling salamanders to urbanization have been understudied historically. Studies on this assemblage have increased sufficiently over the last decade to warrant a review and synthesis of current knowledge. Our survey of the literature indicates a research bias toward species within the Piedmont ecoregion of the USA and a strong emphasis on changes in species richness, relative abundance, and occupancy along an urbanization gradient. Very few investigators have examined vital rates for specific life stages, population dynamics over extended periods, or mechanistic explanations for the specific aspects of urbanization that drive species loss and decline. We reviewed a broad array of literature on stream salamanders to identify the key abiotic and biotic drivers that explain species responses in urban watersheds. Based on these findings and the applied ecological literature, we identified conservation options for urban areas where decision makers and stakeholders wish to preserve stream salamanders and their habitats. We have listed 7 future research priorities that will further efforts to conserve stream salamanders in rapidly urbanizing regions.

Key words: amphibian, Desmognathus, development, Eurycea, impervious surface, suburban, stressors, urban ecology
\end{abstract}

Over half the world's human population resides in urban areas and $\sim 80 \%$ of USA residents inhabit cities (UN 2012). By 2050 the proportion of urban inhabitants in the USA is expected to grow to almost $90 \%$ (UN 2012). The influx of residents to urban centers has resulted in rapid infilling (development of areas that were surrounded by an already developed matrix) and expansion (McDonald et al. 2010, Wu et al. 2010, Sexton et al. 2013). Lotic systems and associated riparian zones often are altered or severely degraded by conversion from rural to urban landscapes (Paul and Meyer 2001, Walsh et al. 2005b, Elmore and Kaushal 2008, Roy et al. 2009). General trends of decline in richness and increases in the abundance of tolerant species of macroinvertebrates and fishes following watershed urbanization are described in a large body of published research (e.g., Weaver and Garman 1994, Wang et al. 2001, Moore and Palmer 2005, Cuffney et al. 2010). This research and subsequent reviews (Paul and Meyer 2001) have proven valuable in critiquing and improving stream-restoration efforts (Walsh et al. 2005a, Violin et al. 2011) and promoting conservation of stream biota (Walsh et al. 2005b).

Amphibians, especially salamanders, are important components of lotic systems, but comparatively little work has been done to evaluate the influence of urbanization on this assemblage. Recent reviews on urbanization and streamassociated biota (Paul and Meyer 2001, Allan 2004, Wenger et al. 2009) have almost entirely neglected this group, and review articles on the effects of urbanization on amphibians have only briefly mentioned stream salamanders (Hamer and McDonnell 2008, Scheffers and Paszkowski 2012). Salamanders are often the dominant predators in low-order stream systems, and probably drive many ecosystem-level processes, such as nutrient cycling, and connect aquatic and terrestrial habitats (Davic and Welsh 2004, Greene et al. 2008, Keitzer and Goforth 2013). Given the importance of salamanders to stream systems and the relative lack of attention they have received in previous reviews, our objectives were 3-fold. First, we characterized existing studies on stream salamander response to urbanization. Second, we moved the conversation about salamander responses to urbanization beyond descriptions of pattern by reviewing a range of studies that helped identify specific mechanisms for observed declines in urbanized watersheds. This review included an exploration of cross-ecoregional patterns and interspecific differences in responses to urbanization. Last, we developed a series of recommendations and considerations for protecting and enhancing stream salamander populations and diversity in urban streams, and we highlighted critical areas

E-mail addresses: ${ }^{3}$ rbarre2@clemson.edu; ${ }^{4}$ To whom correspondence should be addressed, steven.price@uky.edu 
of future research that will inform conservation and management of stream salamanders in an increasingly developed world.

\section{INTRODUCTION TO STREAM SALAMANDER ECOLOGY}

Salamanders are often the dominant vertebrate group in seeps, headwater streams, and other low-order streams (Murphy and Hall 1981, Petranka and Murray 2001, Peterman et al. 2008). This group is incredibly diverse in North and Central America, and stream-associated salamander species in the Hynobiidae are moderately diverse in parts of Europe and Asia. A complete summary of stream salamander ecology is beyond the scope of our review (see Petranka 1998, Mitchell and Gibbons 2010 for more information) and the ecology of many species, particularly members of the Hynobiidae and those in Central America, is not well known. Thus, we focused primarily on stream salamander species of North America.

The genera with the highest species richness in eastern and central North America include brook (Eurycea) and dusky (Desmognathus) salamanders. The genera Cryptobranchus, Gyrinophilus, Pseudotriton, and Necturus have lower species richness but can still play important roles in stream communities (Gustafson 1994). Most species in the genera Eurycea, Desmognathus, Gyrinophilus, and Pseudotriton use streams for reproduction and larval development, then use terrestrial or riparian environments as adults. Giant ( $D i$ camptodon) and torrent (Rhyacotriton) salamanders are strongly associated with low-order streams in the Pacific Northwest. Other North American species (some from the genera Ambystoma, Pseudobranchus, Siren, and Taricha) may use streams and riverine habitats for reproduction or occasional foraging, but most are not entirely dependent on lotic habitats. Salamanders reach their greatest population densities in streams with forested watersheds and intact riparian zones. Estimated densities may be $>150$ larvae $/ \mathrm{m}^{2}$ (Nowakowski and Maerz 2009), but more typically are 10 to $63 \mathrm{larvae} / \mathrm{m}^{2}$ for Eurycea and Desmognathus species combined (Nowakowski and Maerz 2009, Keitzer and Goforth 2013). These densities can vary widely among seasons (Barrett et al. 2010b). Corresponding biomass for temperate forest salamanders often greatly exceeds that of other vertebrates (Burton and Likens 1975). Exceptionally high densities indicate the importance of salamanders as predators (especially of stream invertebrates) that might regulate detritivore populations and indirectly slow the release of nutrients to downstream areas (Milanovich 2010, Keitzer and Goforth 2012, 2013). Furthermore, salamanders are prey for birds, mammals, reptiles, and other animals (Davic 1983, Petranka 1998, Davic and Welsh 2004) and are nutrient vectors linking aquatic and terrestrial environments (Greene et al. 2008).
Results of most studies suggest that local populations of stream salamanders exhibit considerable interannual stability in population size relative to other animal groups. For example, Hairston (1986) counted dusky salamanders (Desmognathus ochrophaeus, Desmognathus quadramaculatus, and Desmognathus monticola) in $140-\mathrm{m}^{2}$ plots on the forest floor and found little variation in the number of adults counted over a 3-y period. Price et al. (2011, 2012a) found relatively stable occupancy rates and abundances of Desmognathus fuscus and Eurycea cirrigera over a 5-y period in $1^{\text {st }}$-order streams in the North Carolina (USA) Piedmont. Populations of stream amphibians exhibit stability because of relatively high annual adult survivorship and a fairly long (2-10 y) adult life span (Organ 1961, Danstedt 1975, Lowe 2003, Price et al. 2012c). Moreover, some species maintain high survivorship (e.g., 0.97 monthly survival) even during stochastic weather events, such as extreme drought (Price et al. 2012b, but see Camp and Tilley 2005). These studies and others (e.g., Green 2003) collectively suggest that local extinction rates are near 0 for many stream-inhabiting amphibian species residing in forested watersheds.

Landscape-scale stream-salamander population stability exists, in part, because most species use both withinnetwork (stream) and overland dispersal. Capture-markrecapture and genetic investigations on stream salamanders have shown that within-network dispersal usually occurs from downstream to upstream sections of streams (Lowe 2003, Lowe et al. 2008, Cecala et al. 2009, Grant et al. 2010), although some species (e.g., Eurycea bislineata and E. cirrigera) may disperse from upstream to downstream sections of streams (Bruce 1986, Lowe et al. 2008). Like pond-breeding amphibians, newly metamorphosed juveniles (individuals that were larvae at time $t-1$ ) have the highest probability of dispersing upstream to other stream reaches or through terrestrial environments, whereas postmetamorphic juveniles (i.e., individuals that were juveniles at time $t-1$ ) and adults show relatively higher rates of site fidelity. Adults have dispersal probabilities near 0 (Grant et al. 2010).

Because of their unique natural history, stream salamanders provide information about the effects of watershed urbanization that macroinvertebrates and fish cannot provide. Unlike strictly aquatic vertebrates (fish) and terrestrial wildlife (birds and mammals), stream salamanders require both aquatic and terrestrial environments to complete their life cycle. Many aquatic macroinvertebrates also have biphasic life cycles, but the terrestrial phase for most of these organisms is very brief and may not include a feeding stage. Stream salamanders breed in aquatic habitats, where urbanizationinduced stressors and environmental conditions may affect egg development, larval growth, and body condition at metamorphosis (Linder et al. 2010). In terrestrial environments in urban areas, juveniles and adults may encounter various 
forms of anthropogenic disturbance, ranging from contaminants to unfavorable land-cover types. Furthermore, larval and adult stream salamanders are carnivores that feed at relatively high trophic levels. In combination with their longevity, salamander population dynamics are likely to integrate responses to chronic exposure from localized anthropogenic stressors (e.g., riparian disturbance or water pollution) across multiple trophic levels. Thus, data gathered on salamander populations can provide unique information on the integrity of urban streams, especially loworder streams (Southerland et al. 2004).

\section{URBANIZATION CHANGES STREAM SALAMANDER DISTRIBUTION, ABUNDANCE, RICHNESS, AND VITAL RATES}

Orser and Shure (1972) were among the first researchers to note that salamander densities were negatively correlated with urbanization. Numerous studies have confirmed these initial findings. For example, Willson and Dorcas (2003) and Miller et al. (2007) found that salamander abundances in the North Carolina Piedmont were inversely proportional to the amount of urban land cover within the stream watershed. In the Georgia Piedmont (USA), stream salamander species richness decreased from 4 species in forested streams to 1 species in urban streams (Barrett and Guyer 2008), and occupancy rates of stream salamander species decreased in urbanized streams in the mid-Atlantic region, USA (Grant et al. 2009). Riley et al. (2005) examined the relationship between urban land cover and amphibian distribution and abundance in southern California streams and found that streams draining watersheds with $\geq 8 \%$ urban land had lower occupancy rates of California newts (Taricha torosa) than streams with no to low urbanization within the watershed. The Jollyville Plateau salamander (Eurycea tonkawae), a species found in only 6 watersheds in central Texas, USA, had greater mean densities at sites in undeveloped than in developed watersheds (Bowles et al. 2006). Some studies have suggested large-scale population declines in rapidly urbanizing regions (Price et al. 2006), but some species may be able to persist in urban areas. Eurycea cirrigera occupied (albeit at lower densities) all surveyed streams surrounded by urbanization in western Georgia (Barrett and Guyer 2008).

The studies described above provide important insights into the effects of urban development on stream salamanders. However, responses to urbanization were characterized primarily by correlations between urban land cover (and associated stream habitat conditions) and salamander occupancy or abundance. Price et al. (2011, 2012a) examined the resilience of stream salamanders to urbanization using a before-after control-impact study design and showed that both larval and adult salamander occupancy and abundance declined precipitously following urbanization. Four years after urbanization of stream watersheds, adult $E$. cirrigera abundances had decreased by an average of $98 \%$, E. cirrigera larvae by $60 \%$, adult $D$. fuscus by $45 \%$, and $D$. fuscus larvae by $49 \%$. Furthermore, larval salamander abundances were significantly lower than in control nonurban streams within $1 \mathrm{y}$ after urbanization, and adult abundances differed from control streams within 2 to $3 \mathrm{y}$. Thus, salamanders are highly sensitive to urbanization of forested land within watersheds.

Relatively few investigators have estimated vital rates (survivorship, recruitment, growth, etc.) of stream salamanders in urban streams. Price et al. (2012c) found that monthly survivorship of $D$. fuscus was $0.758 \pm 0.030$ (SE) in an urban stream, whereas it was $0.880 \pm 0.009$ in a stream with a forested watershed. However, growth rates may be greater in urban streams for certain species. Eurycea cirrigera larvae in urban streams achieved larger sizes than larvae at reference sites within the first few months of growth (Barrett et al. 2010c).

\section{DRIVERS OF SALAMANDER DECLINES IN URBANIZED WATERSHEDS}

Patterns of lower occupancy, abundance, or species richness in urbanized watersheds are well established, but less information is available regarding the proximate mechanisms that explain observed salamander declines. A complex set of interacting factors alters any stream environment that lies within an urbanized watershed (Burcher et al. 2007, Walsh et al. 2005b, Wenger et al. 2009). Such alterations are initiated as water drains into streams from impervious surfaces (Burcher et al. 2007). The physiochemical and biological changes that follow such runoff can vary, but the general patterns of change are consistent (Walsh et al. $2005 \mathrm{~b}$ ). The frequency and intensity of high-flow events increases following urbanization, which alters stream morphology and leads to increases in nutrients and toxicants. These changes and others often lead to dramatic biotic alterations (Walsh et al. 2005b, Wenger et al. 2009). Despite our understanding of what has been called the 'urban stream syndrome' (Walsh et al. 2005b), few studies directly link observed patterns of salamander loss with specific changes to streams or terrestrial environments that result from urban development. Such linkages are valuable because mechanistic understanding of species declines can inform conservation planning and restoration efforts. Below and in Fig. 1, we provide information from a broad array of stream salamander literature on the mechanisms most likely to affect salamander populations in urban streams.

\section{Abiotic drivers}

Abiotic changes to urban stream watersheds have been the focus of most studies on salamander declines in urban habitats. Urbanization leads to burial of many low-order streams (Elmore and Kaushal 2008). As streams are lost, salamander populations inevitably become more discon- 


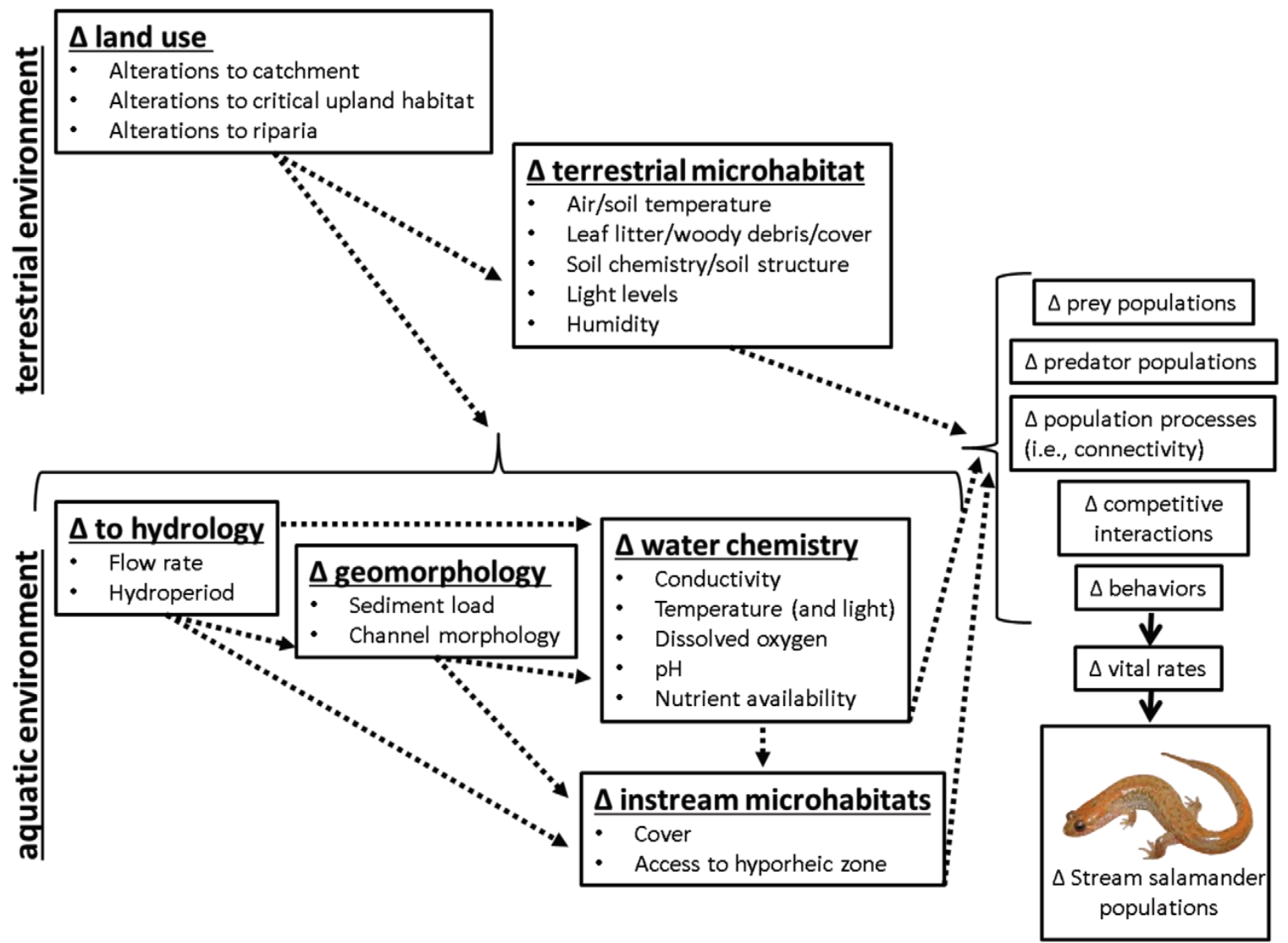

Figure 1. Stressors on stream salamanders in the terrestrial and stream environments in urban areas. $\Delta=$ change(s).

nected, which is likely to have implications for long-term population dynamics of species that can persist within the watershed. Munshi-South et al. (2013) found that remnant populations of $D$. fuscus in New York City (USA) have very little connectivity with one another and low genetic diversity (within populations) relative to desmognathine salamanders sampled over similar distances in reference watersheds. When streams are not directly lost, changes in land cover in watersheds may lead to decreases in abundance or to local extinction, especially for species that depend on terrestrial environments for foraging, migration, or dispersal. Adult E. cirrigera, a species that inhabits streams and surrounding forests (Petranka 1998), were affected by urbanization to a greater extent than $D$. fuscus, a species that spends most of its life in or directly adjacent to streams (Willson and Dorcas 2003, Price et al. 2011, 2012a). Within streams, species movements may be inhibited even by small riparian disturbances, such as canopy gaps created by powerline and road crossings (Cecala 2012). However, attributing salamander declines to direct effects of land-cover change (habitat loss, degradation, fragmentation) is challenging because of the cascading changes to aquatic and terrestrial environments (e.g., hydrology, water chemistry, competitive interactions; Fig. 1) that often follow urbanization.

In urban environments, within-stream connectivity among populations of stream biota may be inhibited by road culverts (Warren and Pardew 1998). Culverts may be installed at slopes inconsistent with stream grade, which can result in a barrier to movement between up- and downstream subpopulations. Such culverts can have water velocities that inhibit the movement of fish species (Warren and Pardew 1998). The influence of culverts (or other road-crossing infrastructure) on salamanders has been the focus of very few studies. However, Sagar et al. (2007) included culvert presence in a candidate model set for coastal giant salamander (Dicamptodon tenebrosus) survival and growth across 14 streams and found equivocal support for the influence of culverts on either response variable. Ward et al. (2008) explicitly evaluated the influence of road crossings on an assemblage of Appalachian salamanders (Plethodontidae) in West Virginia. They found weak evidence for an influence of road crossings on species richness and diversity when these variables were examined at the scale of the entire stream. Evidence for an effect of road crossings on spe- 
cies abundance was stronger, but varied by species. The abundance of $E$. cirrigera increased in streams crossed by roads, but the abundance of other species (Desmognathus spp., Gyrinophilus porphyriticus) decreased (Ward et al. 2008). The study by Ward et al. (2008) focused on streams crossed by single-lane roads. Research focused on the effect of roads in a more urbanized landscape may reveal influences beyond those described by Ward et al. (2008).

Impervious surface caused by roads and other urban surfaces contributes to stream loss, fragmentation of adjacent terrestrial habitat, and significant changes in stream structure and function (Fig. 1). Stream hydrology may be altered by relatively minor increases in the amount of impervious surface in a watershed (Schoonover et al. 2006), and within a site, hydrological changes can alter disturbance frequency, disturbance intensity, and stream size. Konrad and Booth (2005) examined alteration of stream flow following urbanization of streams in the northeastern USA and found an increase in the frequency of high flows and in the amount of water in the stream during low flow. Both of these changes have implications for stream salamanders. First, salamanders tend to exhibit upstream bias in movement and dispersal (Grant et al. 2010), so increases in highflow events may affect dispersal via displacement of individuals from low- to high-order streams or may reduce survivorship. Barrett et al. (2010c) observed lower apparent survivorship of $E$. cirrigera salamander larvae in urban than nonurban streams and used field-based and experimental data to conclude that high-flow events were the most likely cause of these survivorship patterns. Second, at the seasonal time scale, urbanization may alter the presence of some salamanders by preventing low-order streams from drying as a result of lawn irrigation, leaky pipes, and water imported from other watersheds for such uses. Riley et al. (2005) suggested that prolonged hydroperiods in urban streams contributed to the absence of $T$. torosa because a newt predator could colonize permanent streams but not intermittent systems in the region. Prolonged hydroperiods, when present, might facilitate rather than inhibit some salamanders, but we are unaware of any systems where this dynamic has been demonstrated.

High-flow events scour the stream bed and deposit large sediment loads (Walling and Gregory 1970). Increases in these events tend to decrease habitat availability and heterogeneity in urban streams (Davis et al. 2003, Violin et al. 2011), which may decrease the diversity and abundance of stream salamanders (Welsh and Ollivier 1998). Smith and Grossman (2003) compared in-stream habitat at sites where larval E. cirrigera were captured to random sites within the stream. Significantly fewer larvae were found in areas with high \% silt, \% sand, and \% embeddedness, and low levels of wood. These microhabitat features tend to characterize urban stream channels (Walsh et al. 2005b). This result contrasts with results published by Keitzer and Goforth (2012), who studied the influence of sedimentation on the abundance of the Blue Ridge two-lined salamander (Eurycea wilderae) and black-bellied salamander (D. quadramaculatus). In their study, D. quadramaculatus showed some sensitivity to sedimentation, but experimental trials and field sampling suggested that $E$. wilderae abundance was not strongly influenced by sediment loads. Collectively, these studies suggest that sedimentation alone may not be responsible for the negative changes that occur to in-stream habitat and some salamander populations following urbanization. Instead, changes to stream habitats are multifaceted and probably influence species to varying degrees (Keitzer and Goforth 2012).

Materials washing into urban streams also alter water quality, which can have ramifications for stream salamanders (Fig. 1; Barrett et al. 2010a). The effects of urban-stream water quality on salamander diversity and abundance have not been thoroughly documented, perhaps because of the dominant influences of other abiotic changes to stream systems (hydrology and in-stream habitat structure). Poor water quality has been linked to lower stream salamander abundance in agricultural areas relative to forested areas (Muenz et al. 2006). Conductivity was used as a proxy for water quality in the few studies of the relationship between water quality and salamander abundance or diversity in urban streams. Conductivity is a measure of the ability of water to conduct an electrical current. Conductivity can increase as a function of soil and parent material in the watershed, but high conductivity values usually result from road salt, leaky sewer systems, and other urban-related factors. Miller et al. (2007) found support for a correlative model that included conductivity as an explanatory variable for E. cirrigera abundance in an urbanized landscape. In the North Carolina Piedmont, streams with more urbanized watersheds had greater conductivity and lower salamander abundance (Willson and Dorcas 2003). Several other water-quality measures (e.g., dissolved $\mathrm{O}_{2}, \mathrm{pH}$, temperature) may affect salamander populations in urban streams (Woods et al. 2010). Barrett et al. (2010b) examined growth rates of larval E. cirrigera in urban and reference streams and found that elevated water temperatures in urban streams probably explained higher growth rates in those habitats relative to cooler reference streams. Nevertheless, little evidence exists for causative relationships in the studies described here, and we are not aware of any experiments that connect urban water quality to negative trends in growth and abundance of salamanders.

\section{Biotic drivers}

Many investigators have documented dramatic biotic changes in streams as a result of watershed urbanization (see reviews by Paul and Meyer 2001, Wenger et al. 2009). Biotic changes that are most likely to influence stream salamanders include bottom-up effects mediated by shifts in 
the macroinvertebrate assemblage and top-down effects resulting from altered fish composition and abundance. Johnson and Wallace (2005) demonstrated the importance of bottom-up effects on $E$. wilderae during a leaf-litter exclusion experiment. They found lower larval density, biomass, and growth rate in areas where detritus was excluded and suggested that lower macroinvertebrate counts in the stomach contents of salamander larvae from the leaf-litter exclusion treatment supported bottom-up regulation of the study population. The species and structure of woody vegetation in riparian corridors of urban streams often is altered from natural conditions (Roy et al. 2005, Burton and Samuelson 2008), so reduced leaf-litter inputs in urban streams could lead to a bottom-up effect on salamanders similar to that demonstrated by Johnson and Wallace (2005). However, Barrett et al. (2012) examined the diets of E. cirrigera in urban and forested watersheds and found no major differences in overall dietary composition, despite some differences in the macroinvertebrate assemblage (Helms et al. 2009).

The hypothesis that altered fish (or other predator) assemblages accompanying urbanization of a stream might cause decreases in salamander diversity or abundance has not been evaluated explicitly to our knowledge. Barr and Babbitt (2002) demonstrated that predation on salamanders by fish tended to increase in habitats with low cover availability. Hamer and Parris (2013) examined the effect of predation on amphibian communities in urban wetlands and found that altered wetland hydrology, which accompanied urbanization, led to longer hydroperiods. These longer hydroperiods promoted the presence of amphibian predators, which precluded the presence of some amphibian species. Urban streams can increase in size and permanence as a result of altered hydrology (Konrad and Booth 2005, Galster et al. 2008), and these changes may have caused observed increases in salamander predators, such as sunfish (Centrarchidae), in some urbanized streams (Helms et al. 2005, Riley et al. 2005). More research is warranted on topdown influences on salamanders in urban streams.

\section{Interactions between drivers}

Any single mechanism is unlikely to lead to the decline and loss of stream salamanders following urbanization of watersheds. In most cases, a few predominant factors interact to decrease survivorship and colonization (Barrett et al. 2010b). Cecala (2012) approached interacting drivers by establishing an explicit hierarchical modeling framework in which she recognized that changes to the environment at local scales are driven, to varying degrees, by changes that occur across the landscape. Her modeling results strongly supported the positive relationship between forest cover and salamander abundance that many other investigators have identified (Willson and Dorcas 2003, Barrett et al. 2010b, Price et al. 2012a). Correlations with variables measured at local scales were weaker. Many localscale factors (e.g., stream temperature, large woody debris, and chemical composition of the stream) can exhibit much more variation than landscape-scale drivers over the extent of the study, thereby decreasing overall statistical power. The findings of Cecala (2012) illustrate the difficulty of assessing drivers of salamander declines even with large data sets. Burcher et al. (2007) suggested the drivers of species loss following urbanization acted as a series of cascading events that link biotic responses to land-cover alterations. To demonstrate the utility of their model, they used path analysis to identify the abiotic variables that best connected land cover change with shifts in macroinvertebrate and fish assemblages across several watersheds. Barrett et al. (2010c) adapted this approach to investigate causes of E. cirrigera decline in the Georgia Piedmont and were able to establish support for 1 mechanistic pathway among several competing hypotheses; i.e., increased impervious surface leads to increased spate frequency and magnitude, which decreases salamander apparent survivorship.

Other techniques have been used to achieve similar purposes (though not with stream salamanders as the target response): boosted regression trees (Clapcott et al. 2012), neural networks (Dauwalter et al. 2011), and a hierarchical set of redundancy analyses (Hutchens et al. 2009). When derived from natural land-cover gradients, all of these approaches are, to some degree, exploratory in nature, and ultimately provide only correlative lines of evidence. In many cases, such evidence may be sufficient for conservation and management efforts to move forward. When causation must be shown more conclusively, experimental approaches can be derived based on the variables emerging from the analyses listed above.

\section{REGIONAL AND SPECIES DIFFERENCES}

General trends of salamander sensitivity to urban development are well established, and emerging evidence indicates regional and species-specific differences in response to urbanization. For example, in studies of tolerance to development across stream salamander assemblages in the eastern Piedmont, USA, E. cirrigera and D. fuscus typically are the most tolerant species (Willson and Dorcas 2003, Barrett and Guyer 2008, Surasinghe 2013). Willson and Dorcas (2003) and Price et al. (2011, 2012a) found that D. fuscus was more resilient than E. cirrigera in the North Carolina Piedmont, whereas Barrett and Guyer (2008) found that E. cirrigera was the most resilient stream salamander in western Georgia, USA. Why E. cirrigera should be relatively more tolerant of disturbance in Georgia than in North Carolina is not obvious, but the pattern emphasizes the fact that mechanisms driving observations in one place may or may not be a factor in nearby streams. Across ecoregions, Surasinghe (2013) found evidence that D. quadramaculatus and G. porphyriticus were relatively sensitive to develop- 
ment in the Appalachian Blue Ridge but more tolerant in the Piedmont, which demonstrates the potential for geographic variation in response to urbanization within species.

Several mechanisms could explain variation in interand intraspecific responses to urbanization, but few have been evaluated empirically for salamanders. Nevertheless, data on other species or species natural history may provide useful insights. Spatial variation in response to urbanization across ecoregions occurs in macroinvertebrate and fish assemblages in the Coastal Plain streams of Maryland (USA). These groups show lower sensitivity to urban development than similar assemblages in the Piedmont (Utz et al. 2009, 2010). Utz et al. (2010) posited that low topographic relief and abundant wetlands in the Coastal Plain help decrease the high-flow events that can alter urban stream biota. Geographic variation in salamander response to urbanization (e.g., Surasinghe 2013) might possibly be predicted by this mechanism, whereby watersheds with lower slopes can absorb more development before hydrological alterations resulting from impervious surface become sufficient to alter in-stream environments.

Differences in species response also may result from factors specific to the location of the study. Studies of mammals and amphibians (Swihart et al. 2003) and insects (Thomas et al. 2008) indicate that populations are more vulnerable to habitat loss and fragmentation when they are at the margins of the species' geographic ranges. In contrast, Channell and Lomolino (2000) argued that widespread evidence exists for the conservation value of lands at the range margins of many endangered species. The extent to which studies at the range-margin vs range-core of species explain existing data on stream salamander response to urbanization is difficult to evaluate from current knowledge. Most of the studies examining effects of urbanization on salamanders have occurred within core areas of species' range (but see Surasinghe 2013), and data across studies often are not comparable because of differences in sampling techniques. Differences in response to development also may result from local socioeconomics that dictate patterns of development (Kinzig et al. 2005) and variation in the pattern of urbanization within watersheds. For example, vegetation buffers or water-retention features may be mandated by local governments in some regions, but not in others. Ultimately, such differences may result in intraspecific differences across regions.

Variation in natural history among species may partially explain why some species appear to be more sensitive to urbanization than others. For example, species that require both terrestrial and aquatic habitats may be more sensitive than species that use only one habitat type (Crawford and Semlitsch 2007, Price et al. 2011), and the time during which stream salamanders are obligate stream residents ranges widely. Some Desmognathus species are aquatic larvae for
$<1$ y (i.e., D. fuscus and D. ocoee), whereas other species are paedomorphic and spend their entire life in the water (i.e., Cryptobranchus, Necturus, and some Gyrinophilus). Such natural-history differences may contribute to interspecific differences, but no formal tests have been made of relationships between salamander natural-history traits and sensitivity to urbanization.

Last, differences currently suggested by published studies might simply be a result of differences in how response or predictor variables were defined or measured. Understanding which species are most vulnerable under any given set of environmental conditions will be difficult without standardized, large-scale investigations. Nearly all of the research on salamander response to urbanization has focused on the Piedmont ecoregion. However, the Appalachian Mountains are a rapidly developing region and the global center of biodiversity for salamanders. Studies that assess sensitivity of stream salamanders in understudied, speciesrich ecoregions (e.g., Appalachian Mountains, Southeastern Coastal Plain, Interior Plateau, Ozark Highlands, Edwards Plateau of Texas, and the northwestern USA; Fig. 2A, B) could be particularly valuable in helping to contextualize specific mechanisms that are most likely to be responsible for observed declines.

\section{CONSERVATION OPTIONS FOR SALAMANDERS IN URBAN AREAS}

To our knowledge, no investigators have explicitly evaluated conservation options to enhance or protect stream salamander populations in urbanized watersheds. Furthermore, whether management or conservation strategies used to buffer stream biota from disturbances, such as timber harvest, are transferrable to urban landscapes is not clear. Effective strategies will involve identifying key stressors and developing tools to mitigate the impact of these stressors (Wenger et al. 2009). Below we have outlined a few commonsense conservation options that are likely to protect streambreeding salamanders (Table 1). Each of these recommendations warrants further study to evaluate their costs and benefits and their feasibility in urban and suburban settings.

Urbanization often results in removal of vegetation from stream watersheds and alteration of in-stream environments, so protecting critical habitat from degradation associated with urban development is the best way to maintain viable salamander populations in urban and suburban areas. For most stream salamanders, critical habitat comprises instream habitat and adjacent terrestrial environments, including the riparian zone and terrestrial upland habitat (Semlitsch and Bodie 2003, Crawford and Semlitsch 2007). To facilitate dispersal and functioning of population processes, connectivity among patches of critical habitat also should be considered (Semlitsch 2000). Several general strategies in terms of land preservation and management can be 

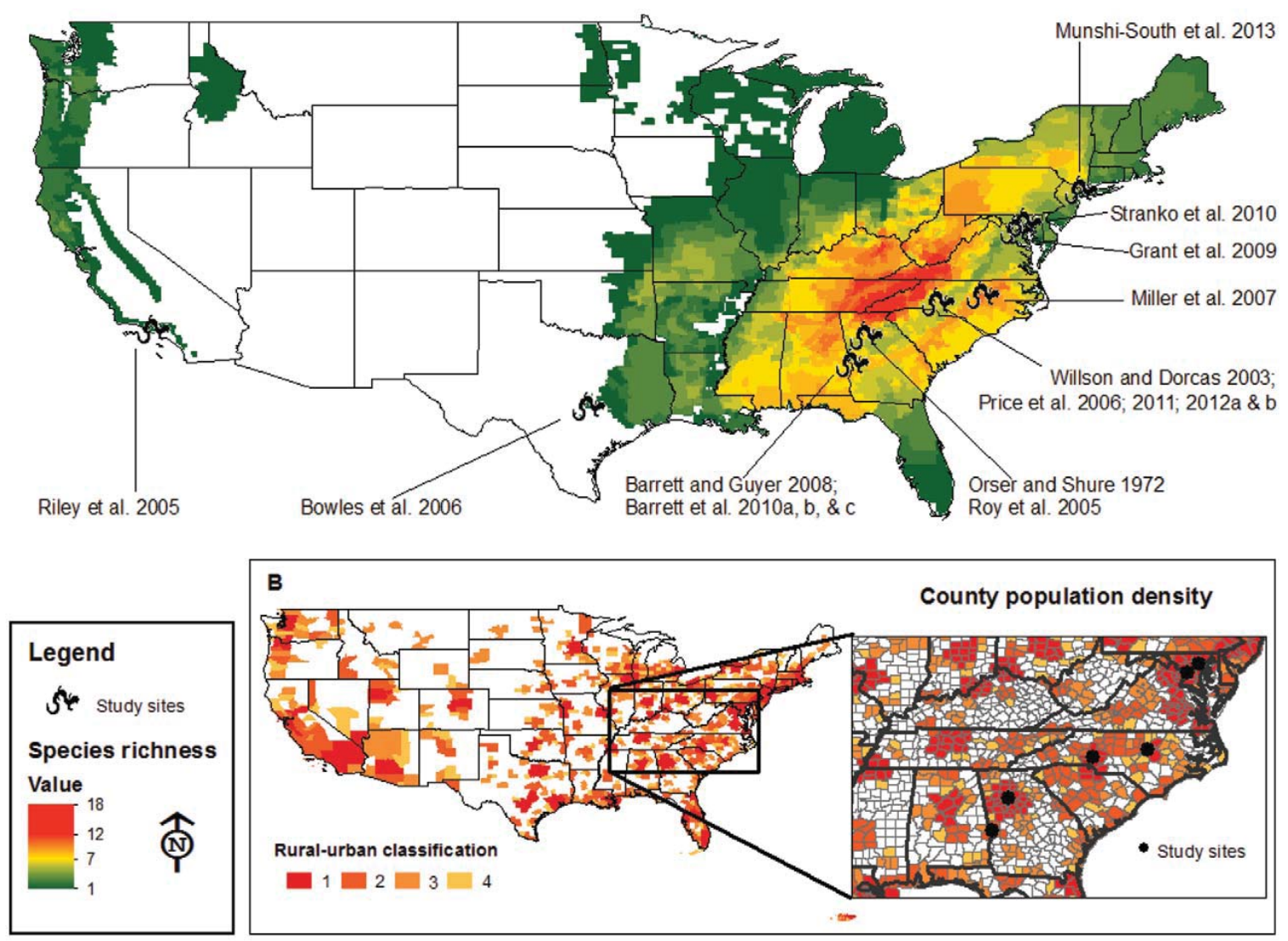

Figure 2. A.-Distribution of stream salamander species richness in North America and sites at which stream salamander responses to urbanization have been studied. Studies included were those known to the authors and those identified in a search (keywords: salamander AND urban* AND stream) of the Web of Science (Thomson Reuters, New York). B.-Degree of urbanization according to the US Department of Agriculture's Rural-Urban Continuum Codes. Inset.-The Rural-Urban Continuum in one of the USA's most species-rich areas for stream salamanders. Rural-Urban Continuum Codes: $1=$ Metro, counties in metropolitan areas of $\geq 1$ million people; $2=$ Metro, counties in metropolitan areas of 250,000 to 1 million people; $3=$ Metro, counties in metropolitan areas of $<250,000$ people; $4=$ Nonmetro, counties with urban population of $\geq 20,000$ people, adjacent to a metropolitan area.

applied to benefit most stream salamander species. First, land-preservation strategies should be based on a species' biology, and the amount and type of land critical to the persistence of the local population of that species should be conserved. Findings by Crawford and Semlitsch (2007) suggest streams should be buffered by $92.6 \mathrm{~m}$ of riparian or terrestrial habitat to protect stream-associated salamander populations in the southern Appalachians. The effectiveness of critical habitat designations for protecting local populations of salamanders, especially in urban areas, may be limited. Willson and Dorcas (2003) and Miller et al. (2007) indicated that even small amounts of impervious surface cover $(\geq 10 \%)$ within stream watersheds could have a profoundly negative effect on stream salamander populations. Thus, we recommend reducing impervious surface cover (i.e., roads, driveways, etc.) in critical habitat. If roads are near streams or in critical habitat, proper measures, such as culverts or underpasses, should be incorporated and de- signed correctly to reduce mortality and facilitate dispersal and migration.

Improving stormwater management and changing human behavior near streams may reduce impacts of development on salamander populations, which appear to be especially susceptible to high-flow events (i.e., Barrett et al. 2010b) and changes in hydroperiod (Riley et al 2005). Maintaining forested buffer zones around streams can decrease the effects of urban and suburban areas on water quality. However, several additional control measures can be used to slow and retain excess water and absorb pollutants associated with stormwater runoff (Tsihrintzis and Hamid 1997). Physical structures, such as stormwater ponds that collect runoff that does not go to water treatment facilities, should be positioned adjacent to streams to prevent chemical contamination, sedimentation, and to reduce the variability of water flow (Tsihrintzis and Hamid 1997, Behera et al. 1999, Harrell and Ranjithan 2003). Nonstructural measures also 
Table 1. Recommendations to enhance urban stream and riparian habitat for salamanders.

Conservation recommendations

1. Protect riparian and critical upland habitat with native vegetation to protect streams

2. Reduce impervious surface cover within riparian and critical upland habitat

3. Use infrastructure (e.g., underpasses) to facilitate movements if roads are near streams and within critical upland habitat

4. Improve stormwater management by using structural and nonstructural measures

5. Restore natural flow and disturbance regime

6. Revegetate and restore riparian and terrestrial environments around streams

7. Promote connectivity among populations by restoring stream networks and terrestrial habitat conditions, possibly through urban greenways

can be used to help prevent pollutants and excess water from entering streams. These measures include public education, street cleaning, fertilizer application control, and zoning to restrict population densities near waterways (Tsihrintzis and Hamid 1997).

Restoration of natural flow and disturbance regimes also may be required to effectively manage salamander populations in urban areas. The removal of stormwater pipes that directly connect impervious surfaces to streams may aid in restoring natural flow and disturbance regimes. Other stream restoration techniques include bank stabilization and provisioning of in-stream structural complexity. These techniques reduce sediment loads and restore in-stream refugia that provide salamanders with microhabitats required for egg deposition and escape from predation (Bernhardt and Palmer 2007). Restoring flow regimes probably will reduce populations of predators (i.e., fish) that lack the adaptations to cope with flow disturbances and will ensure that hydroperiods are suitable to support the life cycles of salamanders.

Revegetation and restoration of riparian zones and terrestrial environments surrounding streams can reduce excessive flows and improve water quality and provide stream salamanders with the terrestrial habitat necessary to complete their life cycles if replanted areas resemble historical vegetation assemblages in composition and structure (Crawford and Semlitsch 2007). Revegetation of riparian zones will benefit salamander populations by supporting insect populations, increasing leaf-litter inputs, and adding woody debris to streams (Roy et al. 2005).

Local restoration efforts may provide some benefit, but Roy et al. (2005) found no difference in the counts of $E$. cirrigera between open- and forested-canopy reaches of suburban streams. Landscape-scale restoration is needed to create connectivity among populations (Brooks et al. 2002, Violin et al. 2011). Methods used to promote connectivity can include restoration of stream networks and creation of corridors in which dispersing salamanders can bypass roads and other less-permeable land-cover types (Aresco 2005, Woltz et al. 2008). Urban greenways are becoming increas- ingly popular in urban planning (Ahern 1995), and placing greenways in riparian zones or adjacent to streams may promote salamander dispersal and provide critical upland habitat. The most effective landscape-scale conservation strategies are likely to be those that concentrate development in already developed watersheds and protect existing forested watersheds to the extent possible (Price et al. 2006).

\section{FUTURE DIRECTIONS}

A decade ago our understanding of how stream salamanders respond to urban development was based largely on 1 study (Orser and Shure 1972). Recent studies have vastly improved our knowledge of how this group responds to urban development, but available data are still scarce relative to data for many other taxa (e.g., plants, aquatic invertebrates, fish, and birds). One region (Piedmont) has been particularly well studied, whereas few studies have been done in most other regions, especially species-rich regions, such as Appalachia (Fig. 2A, B). Here we consider the research directions that are most likely to yield important insights related to ecology and conservation of stream salamanders in urban environments.

1. Ecosystem functioning: Ecosystem functioning can shift after urbanization (Meyer et al. 2005), and elemental imbalances can occur between consumers and the resource base in enriched streams (Cross et al. 2003). The body size and density of salamanders suggests they could play a valuable role in stream nutrient retention, secondary productivity, and the density of emerging aquatic invertebrates (thereby influencing aquatic-terrestrial connectivity). Empirical data such as those collected by Milanovich (2010) and Keitzer and Goforth (2013) are needed to evaluate these potential roles in forested watersheds, and then researchers should assess whether or not the roles change in urban watersheds. 
2. Model generality: Several mechanisms may explain the loss of salamander species and individuals from stream systems. These mechanisms probably act in concert and may be more or less important as a function of the surrounding physiographic province, time since urbanization, and the regional biota. Studies that evaluate model predictive power across multiple systems are sorely needed.

3. Terrestrial life stage: Most of the studies reviewed here focused on the aquatic life stage of stream salamanders. Many of the challenges faced by these organisms could arise from their exposure to the developed riparian and upland areas in which they live as adults. Research is needed on the terrestrial life stages for biphasic salamander species. Major gaps include postmetamorphic survivorship, terrestrial movement patterns in urban and reference landscapes, and terrestrial foodweb interactions involving salamanders.

4. Legacy effects: Incorporating a temporal axis into urban-based studies is essential because watersheds have varying landuse histories and have been urbanized for different lengths of time (Romalho and Hobbs 2012). As urban areas age, arthropod species richness tends to increase (Sattler et al. 2010). Other species, such as birds and frogs, exhibit negative trends between abundance or species richness with urban area age (Loss et al. 2009, Gagne and Fahrig 2010), or for some species, a U-shaped pattern in which abundance is greatest in the youngest and oldest urban areas (Gagne and Fahrig 2010). The nature of this relationship has not been explored for stream salamanders. Empirical evidence is needed to evaluate this hypothesis because a better understanding of how salamander assemblages recover after development would aid overall vulnerability assessments and management plans for this group.

5. Response to restoration and management: The benefit of stream restoration for stream-dwelling species is ambiguous (Palmer et al. 2007), and no investigators have examined the response of stream salamanders to restoration. Restored reaches of urban streams in the North Carolina Piedmont were physically and biologically indistinguishable from unrestored urban stream reaches, and both of those categories were very different from nearby forested streams (Violin et al. 2011). Based on this result, Violin et al. (2011) concluded that reach-scale restoration was not a viable option. Small-scale restoration may still be used to remedy specific problems (e.g., local flooding or unsightly drainages), and these efforts could aid salamander populations.
However, it is not clear whether small-scale efforts assembled patchwork style across the stream network, will yield synergistic or only additive benefits to stream salamanders and other stream biota (Lake et al. 2007). Stream management strategies to facilitate salamander persistence in urban areas also remain understudied. Understanding how salamander assemblages respond to features that reduce flow rate during storm events (e.g., retention ponds, floodplain plantings) would be an excellent first step toward informing management strategies.

6. Community interactions: We know that species richness and species abundance tend to decrease with urban development. When previously competitively dominant species or important predators are lost from streams, how does the remaining community respond? The urban environment quite possibly removes many of the biological interactions that would be present in undeveloped streams, but empirical data are lacking.

7. Other stressors: The issues accompanying urbanization occur in the context of a range of other stressors, such as climate change, disease, and invasive species. These other stressors are likely to be exacerbated by conditions in urban areas (Riley et al. 2005, Bradley and Altizer 2006, Nelson et al. 2009, Kaushal et al. 2010), and studies that address these issues in the context of urban watersheds would offer a more realistic depiction of the full range of stressors species face in these environments (e.g., Stranko et al. 2010).

\section{CONCLUSIONS}

Many investigators have assessed the response of stream fauna to urbanization, but the vast majority of them have either ignored (Paul and Meyer 2001, Walsh et al. 2005b) or only briefly addressed stream salamanders (Hamer and McDonnell 2008). Stream salamanders have a distinct combination of life-history strategies. We think they provide insights on effects of urbanization that are not available when other taxa are studied. The sensitivity of most stream salamanders to development and a few of the most likely mechanisms responsible for observed declines have been demonstrated convincingly (Fig. 1). We used this literature to identify spatial mismatches between research effort and salamander biodiversity (Fig. 2A, B). Future studies that fill these gaps will promote a better understanding of how impacts on stream biota may vary with watershed topography. We assembled promising conservation options (Table 1) to enable salamander persistence in urbanized watersheds, and we identified 7 understudied areas of research that are needed for continued refinement of management and 
conservation actions. As urban areas expand and infill, the need to understand biotic response and mitigate habitat loss will become more pressing. Romalho and Hobbs (2012) recently highlighted the importance of urban studies that address mechanisms of species decline and that incorporate a temporal dimension in study design (i.e., landuse history). We echo these sentiments as they apply to stream salamanders. Moreover, work that brings together scientists in disciplines, such as hydrology, biology, and toxicology, design/development professionals (e.g., city planners, landscape architects, and residential/commercial developers) will be best positioned to mitigate effects of urbanization on biota. Interdisciplinary approaches can move us beyond documenting damage to help dampen the consequences of urbanization on salamanders and other stream organisms (Niemelä 1999).

\section{ACKNOWLEDGEMENTS}

We thank numerous students and colleagues, many from Auburn University, University of Georgia, Clemson University, Davidson College, University of Kentucky, and Wake Forest University, for aiding in field work and in the development and refinement of the ideas we present in this manuscript. In particular, KB thanks S. Samoray, C. Guyer, B. Helms, and K. Cecala for offering ideas, help in the field, or both. SJP thanks R. Browne, K. Cecala, G. Connette, E. Eskew, M. Dorcas, J. Guzy, B. Muncy, and J. Snodgrass for their insights into this topic. Last, we thank C. Oldham, W. Sutton, and G. Connette for reading an earlier draft of this manuscript. Associate Editor Matt Whiles, J. Maerz, and an anonymous referee provided comments and suggestions that improved the manuscript. S. Barrett designed the salamander icons in Fig. 2. Manuscript preparation was partially supported by the School of Agricultural, Forest, and Environmental Sciences at Clemson University and the Department of Forestry at University of Kentucky.

\section{LITERATURE CITED}

Ahern, J. 1995. Greenways as a planning strategy. Landscape and Urban Planning 22:131-155.

Allan, J. D. 2004. Landscapes and riverscapes: the influence of land use on stream ecosystems. Annual Review of Ecology, Evolution, and Systematics 35:257-284

Aresco, M. J. 2005. Mitigation measures to reduce highway mortality of turtles and other herpetofauna at a North Florida lake. Journal of Wildlife Management 69:549-560.

Barr, G. E., and K. J. Babbitt. 2002. Effects of biotic and abiotic factors on the distribution and abundance of larval two-lined salamanders (Eurycea bislineata) across spatial scales. Oecologia (Berlin) 133:176-185.

Barrett, K., and C. Guyer. 2008. Differential responses of amphibians and reptiles in riparian and stream habitats to land use disturbances in western Georgia, USA. Biological Conservation 141:2290-2300.

Barrett, K., C. Guyer, and D. Watson. 2010a. Water from urban streams slows growth and speeds metamorphosis in Fowler's Toad (Bufo fowleri) larvae. Journal of Herpetology 44:297-300.
Barrett, K., B. S. Helms, C. Guyer, and J. E. Schoonover. 2010b. Linking process to pattern: causes of stream-breeding amphibian decline in urbanized watersheds. Biological Conservation 143: 1998-2005.

Barrett, K., B. S. Helms, S. T. Samoray, and C. Guyer. 2010c. Growth patterns of a stream vertebrate differ between urban and forested watersheds. Freshwater Biology 55:1628-1635.

Barrett, K., S. T. Samoray, B. S. Helms, and C. Guyer. 2012. Southern two-lined salamander diets in urban and forested streams in western Georgia. Southeastern Naturalist 11:287-296.

Behera, P., F. Papa, and B. Adams. 1999. Optimization of regional storm-water management systems. Journal of Water Resources and Management Systems 125:107-114.

Bernhardt, E. S., and M. A. Palmer. 2007. Restoring streams in an urbanizing world. Freshwater Biology 52:738-751.

Bowles, B. D., M. S. Sanders, and R. S. Hansen. 2006. Ecology of the Jollyville Plateau salamander (Eurycea tonkawae: Plethodontidae) with an assessment of the potential effects of urbanization. Hydrobiologia 553:111-120.

Bradley, C. A., and S. Altizer. 2006. Urbanization and the ecology of wildlife diseases. Trends in Ecology and Evolution 22: 95-102.

Brooks, S. S., M. A. Palmer, B. J. Cardinale, C. M. Swan, and S. Ribblett. 2002. Assessing stream ecosystem rehabilitation: limitations of community structure data. Restoration Ecology 10: 156-168.

Bruce, R. C. 1986. Upstream and downstream movements of Eurycea bislineata and other salamanders in a southern Appalachian stream. Herpetologica 42:149-155.

Burcher, C. L., H. M. Valett, and E. F. Benfield. 2007. The landcover cascade: relationships coupling land and water. Ecology 88:228-242.

Burton, M. L., and L. J. Samuelson. 2008. Influence of urbanization on riparian forest diversity and structure in the Georgia Piedmont, US. Plant Ecology 195:99-115.

Burton, T. M., and G. E. Likens. 1975. Energy flow and nutrient cycling in salamander populations in the Hubbard Brook Experimental Forest, New Hampshire. Ecology 56:1068-1080.

Camp, C. D., and S. G. Tilley. 2005. Desmognathus ocoee, Ocoee salamander. Pages 719-721 in M. Lannoo (editor). Amphibian declines: the conservation status of United States species. University of California Press, Berkeley, California.

Cecala, K. K. 2012. The role of behavior in influencing headwater salamander responses to anthropogenic development. PhD Dissertation, University of Georgia, Athens, Georgia.

Cecala, K. K., S. J. Price, and M. E. Dorcas. 2009. Evaluating existing movement hypotheses in linear systems using larval stream salamanders. Canadian Journal of Zoology 87:292-298.

Channell, R., and M. V. Lomolino. 2000. Dynamic biogeography and conservation of endangered species. Nature 403:84-86.

Clapcott, J. E., K. J. Collier, R. G. Death, E. O. Goodwin, J. S. Harding, D. Kelly, J. R. Leathwick, and R. G. Young. 2012. Quantifying relationships between land-use gradients and structural and functional indicators of stream ecological integrity. Freshwater Biology 57:74-90.

Crawford, J. A., and R. D. Semlitsch. 2007. Estimation of core terrestrial habitat for stream breeding salamanders and delineation of riparian buffers for protection of biodiversity. Conservation Biology 21:152-158. 
Cross, W. F., J. P. Benstead, A. D. Rosemond, and J. B. Wallace. 2003. Consumer-resource stoichiometry in detritus-based streams. Ecology Letters 6:721-732.

Cuffney, T. F., R. A. Brightbill, J. T. May, and I. R. Waite. 2010. Response of benthic macroinvertebrates to environmental changes associated with urbanization in nine metropolitan areas. Ecological Applications 20:1384-1401.

Danstedt, R. T. 1975. Local geographic variation in demographic parameters and body size of Desmognathus fuscus (Amphibia: Plethodontidae). Ecology 56:1054-1067.

Dauwalter, D. C., S. J. Wenger, K. R. Gelwicks, K. A. Fesenmyer. 2011. Land use associations with distributions of declining native fishes in the Upper Colorado River Basin. Transactions of the American Fisheries Society 140:646-658.

Davic, R. D. 1983. An investigation of salamander guild predation in a North Carolina stream: an experimental approach. $\mathrm{PhD}$ Thesis, Kent State University, Kent, Ohio.

Davic, R. D., and H. H. Welsh. 2004. On the ecological roles of salamanders. Annual Review of Ecology, Evolution, and Systematics 35:405-434.

Davis, N. M., V. Weaver, K. Parks, and M. J. Lydy. 2003. An assessment of water quality, physical habitat, and biological integrity of an urban stream in Wichita, Kansas, prior to restoration improvements (Phase I). Archives of Environmental Contamination and Toxicology 44:1351-1359.

Elmore, A. J., and S. S. Kaushal. 2008. Disappearing headwaters: patterns of stream burial due to urbanization. Frontiers in Ecology and the Environment 6:308-312.

Gagne, S. A., and L. Fahrig. 2010. Effects of time since urbanization on anuran community composition in remnant ponds. Environmental Conservation 37:128-135.

Galster, J. C., F. J. Pazzaglia, and D. Germanoski. 2008. Measuring the impact of urbanization on channel widths using historic aerial photographs and modern surveys. Journal of the American Water Resources Association 44:948-960.

Grant, E. H. C., L. E. Green, and W. H. Lowe. 2009. Salamander occupancy in headwater stream networks. Freshwater Biology 54:1370-1378.

Grant, E. H. C., J. D. Nichols, W. H. Lowe, and W. F. Fagan. 2010. Use of multiple dispersal pathways facilitates amphibian persistence in stream networks. Proceedings of the $\mathrm{Na}$ tional Academy of Sciences of the United States of America 107:6936-6940.

Green, D. M. 2003. The ecology of extinction: population fluctuation and decline in amphibians. Biological Conservation 111: 331-343.

Greene, B. T., W. H. Lowe, and G. E. Likens. 2008. Forest succession and prey availability influence the strength and scale of terrestrial-aquatic linkages in a headwater salamander system. Freshwater Biology 53:2234-2243.

Gustafson, M. P. 1994. Size-specific interactions among larvae of the Plethodontid salamanders Gyrinophilus porphyriticus and Eurycea cirrigera. Journal of Herpetology 28:470-476.

Hairston, N. G. 1986. Species packing in Desmognathus salamanders: experimental demonstration of predation and competition. American Naturalist 127:266-291.

Hamer, A. J., and M. J. McDonnell. 2008. Amphibian ecology and conservation in the urbanizing world: a review. Biological Conservation 141:2432-2449.
Hamer, A. J., and K. M. Parris. 2013. Predation modifies larval amphibian communities in urban wetlands. Wetlands 33:641-652.

Harrell, L., and S. Ranjithan. 2003. Detention pond design and land use planning for watershed management. Journal of Water Resources Planning and Management 129:98-106.

Helms, B. S., J. W. Feminella, and S. Pan. 2005. Detection of biotic responses to urbanization using fish assemblages from small streams of western Georgia, USA. Urban Ecosystems 8:39-57.

Helms, B. S., J. E. Schoonover, and J. W. Feminella. 2009. Seasonal variability of land-use impacts on macroinvertebrate assemblages in streams of western Georgia, USA. Journal of the North American Benthological Society 28:991-1006.

Hutchens, J. J., J. A. Schuldt, C. Richards, L. B. Johnson, G. E. Host, and D. H. Breneman. 2009. Multi-scale mechanistic indicators of midwestern USA stream macroinvertebrates. Ecological Indicators 9:1138-1150.

Johnson, B. R., and J. B. Wallace. 2005. Bottom-up limitation of a stream salamander in a detritus-based food web. Canadian Journal of Fisheries and Aquatic Sciences 62:301-311.

Kaushal, S. S., G. E. Likens, N. A. Jaworski, M. L. Pace, A. M. Sides, D. Seekell, K. T. Belt, D. H. Secor, and R. L. Wingate. 2010. Rising stream and river temperatures in the United States. Frontiers in Ecology and the Environment 8:461-466.

Keitzer, S. C., and R. R. Goforth. 2012. Response of streambreeding salamander larvae to sediment deposition in southern Appalachian (U.S.A.) headwater streams. Freshwater Biology 57:1535-1544.

Keitzer, S. C., and R. R. Goforth. 2013. Spatial and seasonal variation in the ecological significance of nutrient recycling by larval salamanders in Appalachian headwater streams. Freshwater Science 32:1136-1147.

Kinzig, A. P., P. S. Warren, C. Martin, D. Hope, and M. Katti. 2005. The effects of human socioeconomic status and cultural characteristics on urban patterns of biodiversity. Ecology and Society 10:23.

Konrad, C. P., and D. B. Booth. 2005. Hydrologic changes in urban streams and their ecological significance. American Fisheries Society Symposium 47:157-177.

Lake, P. S., N. Bond, and P. Reich. 2007. Linking ecological theory with stream restoration. Freshwater Biology 52:597-615.

Linder, G., C. M. Lehman, and J. R. Bidwell. 2010. Ecotoxicology of amphibians and reptiles in a nutshell. Pages 69-104 in D. W. Sparling, G. Linder, C. A. Bishop, and S. K. Krest (editors). Ecotoxicology of amphibians and reptiles. $2^{\text {nd }}$ edition. SETAC Press, Pensacola Florida.

Loss, S. R., M. O. Ruiz, and J. D. Brawn. 2009. Relationships between avian diversity, neighborhood age, income, and environmental characteristics of an urban landscape. Biological Conservation 142:2578-2585.

Lowe, W. H. 2003. Linking dispersal to local population dynamics: a case study using a headwater salamander system. Ecology 84:2145-2154.

Lowe, W. H., M. A. McPeek, G. E. Likens, and B. J. Cosentino. 2008. Linking movement behavior to dispersal and divergence in plethodontid salamanders. Molecular Ecology 17: 4459-4469.

McDonald, R. I., R. T. T. Forman, and P. Kareiva. 2010. Open space loss and land inequality in United States cities, 19902000. PLoS ONE 5:e9509. 
Meyer, J. L., M. J. Paul, and W. K. Taulbee. 2005. Stream ecosystem function in urbanizing landscapes. Journal of the North American Benthological Society 24:602-612.

Milanovich, J. R. 2010. Modeling the current and future roles of stream salamanders in headwater streams. PhD Dissertation, University of Georgia, Athens, Georgia.

Miller, J., G. Hess, and C. Moorman. 2007. Southern two-lined salamanders in urbanizing watersheds. Urban Ecosystems 10: 73-85.

Mitchell, J., and W. Gibbons. 2010. Salamanders of the southeast. University of Georgia Press, Athens, Georgia.

Moore, A. A., and M. A. Palmer. 2005. Invertebrate biodiversity in agricultural and urban headwater streams: implications for conservation and management. Ecological Applications 15:1169-1177.

Muenz, T. K., S. W. Golladay, G. Vellidis, and L. L. Smith. 2006. Stream buffer effectiveness in an agriculturally influenced area, southwestern Georgia: responses of water quality, macroinvertebrates, and amphibians. Journal of Environmental Quality 35: 1924-1938.

Munshi-South, J., Y. Zak, and E. Pehek. 2013. Conservation genetics of extremely isolated urban populations of the northern dusky salamander (Desmognathus fuscus) in New York City. PeerJ 1:e64.

Murphy, M. L., and J. D. Hall. 1981. Varied effects of clear-cut logging on predators and their habitat in small streams of the Cascade Mountains, Oregon. Canadian Journal of Fisheries and Aquatic Sciences 38:137-145.

Nelson, K. C., M. A. Palmer, J. E. Pizzuto, G. E. Moglen, P. L. Angermeier, R. H. Hilderbrand, M. Dettinger, and K. Hayhoe. 2009. Forecasting the combined effects of urbanization and climate change on stream ecosystems: from impacts to management options. Journal of Applied Ecology 46:154163.

Niemelä, J. 1999. Ecology and urban planning. Biodiversity and Conservation 8:119-131.

Nowakowski, A. J., and J. C. Maerz. 2009. Estimation of larval stream salamander densities in three proximate streams in the Georgia Piedmont. Journal of Herpetology 43:503-509.

Organ, J. A. 1961. Studies of the local distribution, life history, and population dynamics of the salamander genus Desmognathus in Virginia. Ecological Monographs 31:189-220.

Orser, P. N., and D. J. Shure. 1972. Effects of urbanization on the salamander Desmognathus fuscus fuscus. Ecology 53:11481154.

Palmer, M. A., R. F. Ambrose, and N. L. Poff. 2007. Ecological theory and community restoration ecology. Restoration Ecology 5:291-300.

Paul, M. J., and J. L. Meyer. 2001. Streams in the urban landscape. Annual Review of Ecology, Evolution, and Systematics 32:333-365.

Peterman, W. E., J. A. Crawford, and R. D. Semlitsch. 2008. Productivity and significance of headwater streams: population structure and biomass of the black-bellied salamander (Desmognathus quadramaculatus). Freshwater Biology 53:347-357.

Petranka, J. W. 1998. Salamanders of the United States and Canada. Smithsonian Institution Press, Washington, DC.

Petranka, J. W., and S. S. Murray. 2001. Effectiveness of removal sampling for determining salamander density and biomass: a case study in an Appalachian streamside community. Journal of Herpetology 35:36-44.

Price, S. J., R. A. Browne, and M. E. Dorcas. 2012a. Evaluating the effects of urbanisation on salamander abundances using a before-after control-impact design. Freshwater Biology 57: 193-203.

Price, S. J., R. A. Browne, and M. E. Dorcas. 2012b. Resistance and resilience of a stream salamander to supraseasonal drought. Herpetologica 68:312-323.

Price, S. J., K. K. Cecala, R. A. Browne, and M. E. Dorcas. 2011. Effects of urbanization on occupancy of stream salamanders. Conservation Biology 27:547-555.

Price, S. J., M. E. Dorcas, A. L. Gallant, R. W. Klaver, and J. D. Willson. 2006. Three decades of urbanization: estimating the impact of land cover change on stream salamander populations. Biological Conservation 133:436-441.

Price, S. J., E. A. Eskew, K. K. Cecala, R. A. Browne, and M. E. Dorcas. 2012c. Estimating survival of a streamside salamander: importance of temporary emigration, capture response and location. Hydrobiologia 679:205-215.

Riley, S. P. D., G. T. Busteed, L. B. Kats, T. L. Vandergon, L. F. S. Lee, R. G. Dagit, J. L. Kerby, R. N. Fisher, and R. M. Sauvajot. 2005. Effects of urbanization on the distribution and abundance of amphibians and invasive species in southern California streams. Conservation Biology 19:1894-1907.

Romalho, C. E., and R. J. Hobbs. 2012. Time for a change: dynamic urban ecology. Trends in Ecology and Evolution 27: 179-188.

Roy, A. H., A. L. Dybas, K. M. Fritz, and H. R. Lubbers. 2009. Urbanization affects the extent and hydrologic permanence of headwater streams in a Midwestern US metropolitan area. Journal of the North American Benthological Society 28:911928.

Roy, A. H., C. L. Faust, M. C. Freeman, and J. L. Meyer. 2005. Reach-scale effects of riparian forest cover on urban stream ecosystems. Canadian Journal of Fisheries and Aquatic Sciences 62:3212-2329.

Sagar, J. P., D. H. Olson, and R. A. Schmitz. 2007. Survival and growth of larval coastal giant salamanders (Dicamptodon tenebrosus) in streams in the Oregon Coast Range. Copeia 2007:123-130.

Sattler, T., P. Duelli, M. K. Obrist, R. Arlettaz, and M. Moretti. 2010. Response of arthropod species richness and functional groups to urban habitat structure and management. Landscape Ecology 25:941-954.

Scheffers, B. R., and C. A. Paszkowski. 2012. The effects of urbanization on North American amphibian species: identifying new directions for urban conservation. Urban Ecosystems 15:133-147.

Schoonover, J. E., B. G. Lockaby, and B. S. Helms. 2006. Impacts of land cover on stream hydrology in the west Georgia Piedmont, USA. Journal of Environmental Quality 35:2123-2131.

Semlitsch, R. D. 2000. Principles for management of aquatic breeding amphibians. Journal of Wildlife Management 64:615631.

Semlitsch, R. D., and J. R. Bodie. 2003. Biological criteria for buffer zones around wetlands and riparian habitats for amphibians and reptiles. Conservation Biology 17:1219-1228.

Sexton, J. O., X. Song, C. Huang, S. Channan, M. E. Baker, and J. R. Townshend. 2013. Urban growth of the Washington 
D.C.-Baltimore MD metropolitan region from 1984 to 2010 by annual, Landsat-based estimates of impervious cover. Remote Sensing of Environment 129:42-53.

Smith, S., and G. D. Grossman. 2003. Stream microhabitat use by larval southern two-lined salamanders in the Georgia Piedmont. Copeia 2003:531-543.

Southerland, M. T., R. E. Jung, D. P. Baxter, I. C. Chellman, G. Mercurio, and J. H. Vølstad. 2004. Stream salamanders as indicators of stream quality in Maryland, USA. Applied Herpetology 2:23-46.

Stranko, S. A., S. E. Gresens, R. J. Klauda, J. V. Kilian, P. J. Ciccotto, M. J. Ashton, and A. J. Becker. 2010. Differential effects of urbanization and non-natives on imperiled stream species. Northeastern Naturalist 17:593-614.

Surasinghe, T. D. 2013. Influences of riparian land-uses on habitat use and interspecific competition of stream-dwelling salamanders: evidence from Blue Ridge and Piedmont. PhD Dissertation, Clemson University, Clemson, South Carolina.

Swihart, R. K., T. M. Gehring, M. B. Kolozsvary, and T. E. Nupp. 2003. Responses of "resistant" vertebrates to habitat loss and fragmentation: the importance of niche breadth and range boundaries. Diversity and Distributions 9:1-18.

Thomas, C. D., C. R. Bulman, and R. J. Wilson. 2008. Where within a geographical range do species survive best? A matter of scale. Insect Conservation and Diversity 1:2-8.

Tsihrintzis, V. A., and R. Hamid. 1997. Modeling and management of urban stormwater runoff quality: a review. Water Resources Management 11:137-164.

UN (United Nations). 2012. World urbanization prospects: the 2011 revision. Department of Economic and Social Affairs, Population Division, United Nations, New York.

Utz, R. M., R. H. Hilderbrand, and D. M. Boward. 2009. Identifying regional differences in threshold responses of aquatic invertebrates to land cover gradients. Ecological Indicators 9: $556-567$.

Utz, R. M., R. H. Hilderbrand, and R. L. Raesly. 2010. Regional differences in patterns of fish species loss with changing land use. Biological Conservation 143:688-699.

Violin, C. R., P. Cada, E. B. Sudduth, B. A. Hassett, D. L. Penrose, and E. S. Bernhardt. 2011. Effects of urbanization and urban stream restoration on the physical and biological structure of stream ecosystems. Ecological Applications 21:1932-1949.

Walling, D. E., and K. J. Gregory. 1970. The measurement of the effects of building construction on drainage basin dynamics. Journal of Hydrology 11:129-144.

Walsh, C. J., T. D. Fletcher, and A. R. Ladson. 2005a. Stream restoration in urban catchments through redesigning storm- water systems: looking to the catchment to save the stream. Journal of the North American Benthological Society 24: 690-705.

Walsh, C. J., A. H. Roy, J. W. Feminella, P. D. Cottingham, P. M. Groffman, and R. P. Morgan. 2005b. The urban stream syndrome: current knowledge and the search for a cure. Journal of the North American Benthological Society 24:706723.

Wang, L., J. Lyons, and P. Kanehl. 2001. Impacts of urbanization on stream habitat and fish across multiple spatial scales. Environmental Management 28:255-266.

Ward, R. L., J. T. Anderson, and J. T. Petty. 2008. Effects of road crossings on stream and streamside salamanders. Journal of Wildlife Management 72:760-771.

Warren, M. L., and M. G. Pardew. 1998. Road crossings as barriers to small-stream fish movement. Transactions of the American Fisheries Society 127:637-644.

Weaver, L. A., and G. C. Garman. 1994. Urbanization of a watershed and historical changes in a stream fish assemblage. Transactions of the American Fisheries Society 123:162-172.

Wenger, S. J., A. H. Roy, C. R. Jackson, E. S. Bernhardt, T. L. Carter, S. Filoso, C. A. Gibson, W. C. Hession, S. S. Kaushal, E. Martí, J. L. Meyer, M. A. Palmer, M. J. Paul, A. H. Purcell, A. Ramírez, A. D. Rosemond, K. A. Schofield, E. B. Sudduth, and C. J. Walsh. 2009. Twenty-six key research questions in urban stream ecology: an assessment of the state of the science. Journal of the North American Benthological Society 28: 1080-1098.

Welsh, H. H., and L. M. Ollivier. 1998. Stream amphibians as indicators of ecosystem stress: a case study from California redwoods. Ecological Applications 8:1118-1132.

Willson, J. D., and M. E. Dorcas. 2003. Effects of habitat disturbance on stream salamanders: implications for buffer zones and watershed management. Conservation Biology 17:763771.

Woltz, H. W., J. P. Gibbs, and P. K. Ducey. 2008. Road crossing structures for amphibians and reptiles: informing design through behavioral analysis. Biological Conservation 141:27452750.

Woods, H. A., M. F. Poteet, P. D. Hitchings, R. A. Brain, and B. W. Brooks. 2010. Conservation physiology of the Plethodontid salamanders Eurycea nana and E. sosorum: response to declining dissolved oxygen. Copeia 2010:540-553.

Wu, J., G. D. Jenerette, A. Buyantuyev, and C. L. Redman. 2010. Quantifying spatiotemporal patterns of urbanization: the case of the two fastest growing metropolitan regions in the United States. Ecological Complexity 8:1-8. 